\title{
Tapeworms (Cestoda: Proteocephalidea) of firewood catfish Sorubimichthys planiceps (Siluriformes: Pimelodidae) from the Amazon River
}

\author{
Alain de Chambrier ${ }^{1}$ and Tomáš Scholz ${ }^{2}$ \\ ${ }^{1}$ Département des Invertébrés, Muséum d'histoire naturelle, P.O. Box 6434, CH-1211 Geneva 6, Switzerland; \\ ${ }^{2}$ Institute of Parasitology, Biology Centre, Academy of Sciences of the Czech Republic, Branišovská 31, 37005 České \\ Budějovice, Czech Republic
}

Key words: Cestoda, Lenhataenia gen. n., morphology, species survey, identification key, redescriptions, freshwater fish, Brazil, Peru

\begin{abstract}
A survey of proteocephalidean cestodes found in the firewood catfish Sorubimichthys planiceps (Spix et Agassiz) from the Amazon River is provided. The following taxa parasitic in S. planiceps are redescribed on the basis of their type specimens and material collected recently in the Amazon River, near the type localities in Brazil, and in Iquitos, Peru: Monticellia lenha Woodland, 1933; Nomimoscolex lenha (Woodland, 1933) (syn. Proteocephalus lenha Woodland, 1933); and Monticellia megacephala Woodland, 1934, for which a new genus, Lenhataenia, is proposed, with L. megacephala (Woodland, 1934) comb. n. as its type and only species. The new genus is a member of the Monticelliinae, i.e. has all genital organs in the cortex, and is most similar to Chambriella in possessing biloculate suckers and lacking a metascolex. It differs in the morphology of the cirrussac that contains a strongly coiled, thick-walled internal sperm duct (vas deferens) and a muscular cirrus of the appearance typical of most proteocephalideans, whereas that of Chambriella is sigmoid, with voluminous, tightly sinuous thick-walled internal sperm duct. In addition, Lenhataenia possesses a well developed internal musculature, whereas the internal musculature of Chambriella is weakly developed, formed by a low number of muscle fibres. The scolex morphology and distribution of microtriches of Peltidocotyle lenha (Woodland, 1933) (syn. Othinoscolex lenha Woodland, 1933 and Othinoscolex myzofer Woodland, 1933), Chambriella sp. and Choanoscolex sp. are described using scanning electron microscopy. The two latter taxa may be new for science and are reported from S. planiceps for the first time.
\end{abstract}

Woodland $(1933,1934)$ described the following five taxa of proteocephalidean cestodes from "peixe lenha" collected in the Amazon River, Brazil in 1931: Othinoscolex lenha Woodland, 1933; O. myzofer Woodland, 1933; Monticellia lenha Woodland, 1933; Proteocephalus lenha Woodland, 1933; and Monticellia megacephala Woodland, 1934. The teleost host was considered to be the long-whiskered catfish Platystomatichthys sturio (Kner, 1858) (Siluriformes: Pimelodidae). However, it is obvious from Woodland's description of the fish examined that he actually misidentified the firewood catfish [Sorubimichthys planiceps (Spix et Agassiz, 1829)], the vernacular name of which in the Brazilian Amazonia is also "peixe lenha" (Froese and Pauly 2007). The hosts that harboured the proteocephalidean tapeworms described by Woodland $(1933,1934)$ were characterised as large (58-110 cm long) and "slaty grey or dark green in hue with black spots, a flat head with a projecting spatulate upper jaw and long maxillary barbels" (Woodland 1933 - p. 491). This description corresponds perfectly to the firewood catfish, not to the longwhiskered catfish, which is much smaller (maximum size $40 \mathrm{~cm}$ only), bears a long pointed upper jaw, has a grey and white colour and lacks numerous black spots
(Froese and Pauly 2007). Platystomatichthys sturio also possesses a caudal fin with extremely long posterior filaments, which was not mentioned by Woodland (1933) as a characteristic feature of the teleost host. In addition, newly collected fish hosts from the region where Woodland found his material in Brazil and from additional localities (Peru) harboured the identical cestode fauna. Therefore, it is obvious that firewood catfish, S. planiceps, was the actual type host of all Woodland's taxa, as already assumed by de Chambrier and Vaucher $(1999-$ p. 221).

The type specimens of Woodland $(1933,1934)$ were fragmented and often pieces of more than one taxon were placed on the same slide. This mixture of species and their incomplete and sometimes even erroneous descriptions resulted in subsequent taxonomic problems and confusions, including homonymies, because the species name "lenha" was used by Woodland (1933) for as many as three related taxa.

In order to clarify the species composition of proteocephalidean cestodes parasitic in Neotropical teleost fish, almost all of Woodland's type material, of which majority is deposited in The Natural History Museum in London, has been examined and the taxa revised ac- 
cordingly by the senior author (see, e.g., de Chambrier and Vaucher 1997, 1999, Gil de Pertierra and de Chambrier 2000, Zehnder and de Chambrier 2000, Carfora et al. 2003, de Chambrier 2003, de Chambrier et al. 2005, 2006a, de Chambrier and Scholz 2005). These revisions of type specimens and examination of extensive materials of proteocephalideans recently collected from firewood catfish (S. planiceps) in the Amazon River, Brazil and Peru enabled us to critically evaluate the species composition and taxonomic status of the tapeworms reported to occur in this catfish.

Based on the examination of the type material and the newly collected material, only one of the five species described by Woodland $(1933,1934)$ is considered still valid as originally described (Monticellia lenha see de Chambrier and Vaucher 1999); two species were transferred to other genera (Othinoscolex lenha now valid as Peltidocotyle lenha and Proteocephalus lenha now valid as Nomimoscolex lenha - see Zehnder and de Chambrier 2000 and de Chambrier et al. 2004); one became a synonym of another species (Othinoscolex myzofer synonym of Peltidocotyle lenha - see Zehnder and de Chambrier 2000); and one (Monticellia megacephala) is deserving of a new genus, described herein. In addition, three of these taxa are also redescribed in the present paper.

\section{MATERIALS AND METHODS}

The type specimens of all five species described by Woodland $(1933,1934)$, which are deposited in The Natural History Museum in London (acronym BMNH), were studied using Nomarski differential contrast microscopy: (i) two whole mounts and five slides with cross- and frontal sections of syntypes of Othinoscolex lenha (BMNH 1964.12.15.87-93); (ii) two whole mounts of syntypes of Othinoscolex myzofer (BMNH 1964.12.15.94-100); (iii) four whole mounts and five slides with cross-sections of cotypes of Monticellia lenha (BMNH 1964.12.15.225-231); (iv) four whole mounts and three slides with cross-sections of cotypes of Proteocephalus lenha (BMNH 1964.12.15.123-127); (v) five whole mounts and seven slides with cross-sections of cotypes of Monticellia megacephala (BMNH 1964.12.15.199-205).

The following tapeworms, now deposited in the Natural History Museum in Geneva (acronym INVE) and the Institute of Parasitology, České Budějovice (acronym IPCAS), were newly collected by the present authors from $S$. planiceps from the Amazon River in Brazil and Peru: (i) Peltidocotyle lenha: five specimens from Itacoatiara, Brazil $\left(03^{\circ} 08^{\prime} 34^{\prime \prime} \mathrm{S}\right.$, $\left.58^{\circ} 26^{\prime} 38^{\prime \prime} \mathrm{W}\right)$ collected by A. de Chambrier on 15.9.1992 (eight of nine fish infected) (INVE 22026) and on 219.10.1995 (INVE 21881-21884); one specimen from Iquitos, Peru $\left(03^{\circ} 82^{\prime} \mathrm{S}, 72^{\circ} 30^{\prime} \mathrm{W}\right)$ collected by T. Scholz and R. Kuchta on 10.9.2006 (five of nine fish infected) (INVE 54605); (ii) Monticellia lenha: ten specimens from Itacoatiara, Brazil, collected by A. de Chambrier on 15.9.1992 (INVE 19510) and
1-21.10.1995 (INVE 20500, 21885, 22052, 22074, 25098, 34066) (all nine fishes were infected); seven specimens from Iquitos, Peru, collected by T. Scholz and R. Kuchta on 916.9.2006 (six of nine fishes infected) (INVE 54628; IPCAS C-481); (iii) Nomimoscolex lenha: two specimens from Itacoatiara, Brazil, collected by A. de Chambrier on 2.10.1995 and 21.10.1995 (two of nine fishes infected) (INVE 20697, 22076); one specimen from Iquitos, Peru, collected by $\mathrm{T}$. Scholz and R. Kuchta on 9.9.2006 (one of nine fishes infected) (INVE 54629; IPCAS C-477); (iv) Monticellia megacephala: nine specimens from Itacoatiara, Brazil, collected by A. de Chambrier on 15.9.1992, 2.10. and 21.10.1995 (three of nine fishes infected) (INVE 22025, 20768, 22077); four specimens from Iquitos, Peru, collected by T. Scholz and R. Kuchta on 9-10.9.2006 (two of nine fishes infected) (INVE 54608; IPCAS C-480); (v) Chambriella sp.: five specimens from Itacoatiara, Brazil, collected by A. de Chambrier on 15.9.1992 and 2.10.1995 (two of nine fishes infected) (INVE 20768, 22027); eight specimens from Iquitos, Peru, collected by T. Scholz and R. Kuchta on 9.9.2006 (one of nine fishes infected) (INVE 54609, 54632; IPCAS C-478); (vi) Choanoscolex sp.: numerous specimens from Itacoatiara, Brazil, collected by A. de Chambrier on 15.9.1992 and 2-21.10.1995 (four of nine fishes infected) (INVE 19951, 25095-97, 22077, 22078); one specimen from Iquitos, Peru, collected by T. Scholz and R. Kuchta on 9.9.2006 (two of nine fishes infected) (IPCAS C-479).

The newly collected tapeworms were fixed immediately after dissection of the hosts with hot $4 \%$ neutral formaldehyde solution and then stored in $75 \%$ ethanol. They were stained with Mayer's hydrochloric carmine solution, dehydrated in a graded ethanol series, cleared with eugenol (clove oil) and mounted in Canada balsam. Pieces of strobila were embedded in paraffin wax, transversely sectioned at $12-15 \mu \mathrm{m}$, stained with Weigert's haematoxylin and counterstained with $1 \%$ eosin B (acidified with five drops of pure acetic acid for 100 ml solution)

One specimen of Monticellia lenha and Nomimoscolex lenha from Brazil (Woodland's material) and six specimens of M. lenha, Monticellia megacephala, Chambriella sp. and Choanoscolex sp. from Peru were prepared for scanning electron microscopy (SEM) as follows: specimens were dehydrated in a graded ethanol series, then transferred to graded amyl/acetate series, critical point-dried in $\mathrm{CO}_{2}$, sputter coated with gold and examined in a Zeiss DSM 940A electron microscope at the Natural History Museum, Geneva. Eggs were studied in distilled water. Microthrix terminology follows that of Thompson et al. (1980) and Hoberg et al. (1995). All measurements are given in micrometres unless otherwise indicated; data on the type material (TM) are in parentheses. Abbreviations used in descriptions are as follows: $\mathrm{x}=$ mean; $\mathrm{CV}=$ coefficient of variability $[\mathrm{x} / \mathrm{standard}$ deviation $(\mathrm{SD}) \times 100$ (in $\%)] ; n=$ number of measurements; $\mathrm{OV}=$ ratio of the width of the ovary versus the width of the proglottid (in \%); $\mathrm{PC}=$ ratio of the length of the cirrus-sac versus the width of the proglottid (in \%); PP = position of the genital pore (cirrus pore) in $\%$ of the length of the proglottid. 


\section{RESULTS}

\section{Survey of species from Sorubimichthys planiceps, their taxonomic status and phylogenetic position}

(1) Peltidocotyle lenha (Woodland, 1933) Woodland, 1934

Figs. 1,2

Synonyms: Othinoscolex lenha Woodland, 1933; Othinoscolex myzofer Woodland, 1933; Woodlandiella myzofer (Woodland, 1933) Freze, 1965 as Woodlandiella myzofera by Freze (1965).

Remarks. Woodland (1933) described the species from three tapeworms found in "peixe lenha" from the Amazon River 50 miles below Santarem, Brazil (field number Amaz 92). The same author (Woodland 1934) transferred the species to Peltidocotyle Diesing, 1850 as Peltidocotyle lenha (Woodland, 1933) because of the synonymy of Othinoscolex Woodland, 1933 with Peltidocotyle Diesing, 1850. This new combination was widely accepted and is currently considered to be valid by most recent authors (Schmidt 1986, Zehnder and de Chambrier 2000, de Chambrier et al. 2004, 2006b, Hypša et al. 2005).

Othinoscolex myzofer was established by Woodland (1933), who found 24 specimens in two fishes caught in the Amazon River, one fish ten miles below Itacoatiara (field number Amaz 78) and another one about eight miles below Obydos (Óbidos in Portuguese) (field number Amaz 120). One year later, Woodland (1934) transferred the species to Peltidocotyle, but Freze (1965) did not accept this new combination because of the alleged absence of suckers in $O$. lenha. Consequently, he proposed a new genus, Woodlandiella, to accommodate Othinoscolex myzofer (Woodland, 1933) Freze, 1965 as a new combination (misspelled as Woodlandiella myzofera by Freze 1965). Zehnder and de Chambrier (2000) found the suckers of the type material of Othinoscolex myzofer and $O$. lenha to be identical and synonymized O. myzofer with O. lenha; Woodlandiella Freze, 1965 became a junior synonym of Peltidocotyle Diesing, 1850.

Peltidocotyle lenha has recently been redescribed by Zehnder and de Chambrier (2000), based on the type specimens and new material from the firewood catfish and black manguruyu, Paulicea luetkeni (Steindachner) (Pimelodidae), from Brazil (Amazon and Paraná Rivers) and Paraguay (Paraguay River). Molecular analyses based on sequences of four genes (Zehnder and Mariaux 1999, de Chambrier et al. 2004, Hypša et al. 2005) grouped in all analyses $P$. lenha with the type species of Peltidocotyle, $P$. rugosa Diesing, 1850. This small clade formed a sister group to most Neotropical proteocephalideans parasitic in siluriform fish (Hypša et al. 2005).
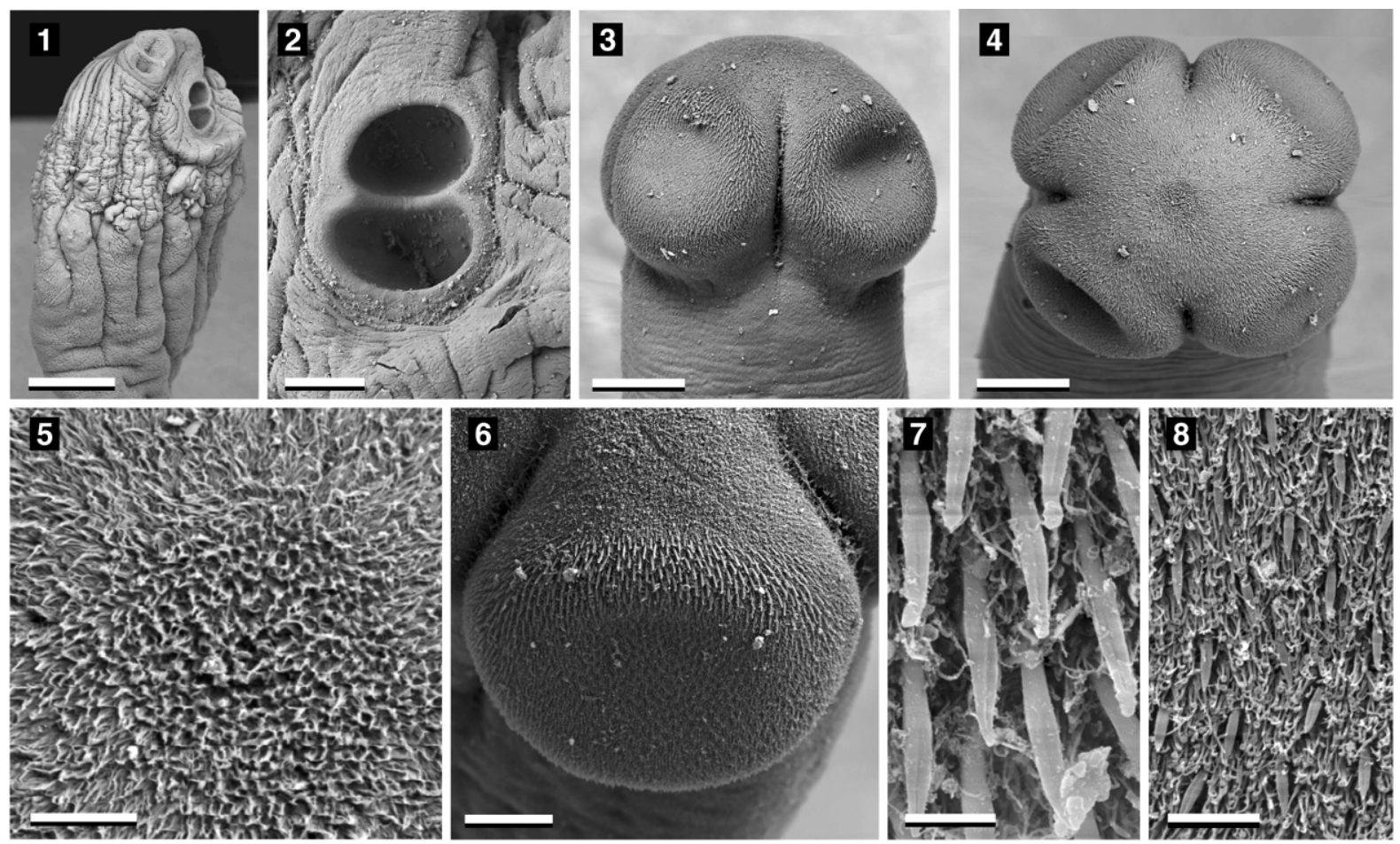

Figs. 1-8. Scanning electron micrographs. Figs. 1, 2. Scolex of Peltidocotyle lenha (Woodland, 1933) Woodland, 1934 (INVE 54605). Fig. 1. Dorsoventral view. Fig. 2. Biloculate sucker. Figs. 3-8. Scolex of Monticellia lenha Woodland, 1933. Fig. 3. Dorsoventral view (INVE 54606). Fig. 4. Apical view (INVE 54606). Fig. 5. Filiform microtriches on the apex of scolex (INVE 54606). Fig. 6. Anterolateral view of sucker with large blade-like spiniform microtriches (INVE 54607). Fig. 7. Large blade-like spiniform microtriches interspersed with filiform microtriches on anterior margin of suckers (INVE 54607). Fig. 8. Large bladelike spiniform and filiform microtriches in internal cavity of suckers. Scale bars: Fig. $1=400 \mu \mathrm{m}$; Fig. $2=100 \mu \mathrm{m}$; Figs. 3 , $4=$ $60 \mu \mathrm{m}$; Fig. $5=10 \mu \mathrm{m}$; Fig. $6=30 \mu \mathrm{m}$; Figs. $7,8=5 \mu \mathrm{m}$. 
(2) Monticellia lenha Woodland, 1933

Figs. 3-8, 20-24

Synonym: Spasskyellina lenha (Woodland, 1933) Freze, 1965.

Redescription (based on cotypes BMNH 1964.12. 15.225-231 and ten specimens from S. planiceps from Brazil and Peru; means and number of measurements are not included if less than four measurements were taken): Proteocephalidae, Monticelliinae. Testes, ovary, vitelline follicles and uterus cortical. Worms up to 14 $35 \mathrm{~mm}$ long $(\mathrm{TM}=24-28 \mathrm{~mm} ; 30 \mathrm{~mm}$ according to Woodland 1933) and 990 wide $(\mathrm{TM}=935 ; 1 \mathrm{~mm}$ according to Woodland 1933). Strobila acraspedote, in two complete specimens consisting of $66-88$ proglottids: 54-59 immature (up to appearance of spermatozoa in vas deferens), 9-13 mature (up to appearance of eggs in uterus), 5-13 pregravid (up to appearance of hooks in oncospheres) and 3 gravid.

Internal longitudinal musculature developed (Figs. 22,23 ), forming anastomosed bundles of muscle fibres. Ventral osmoregulatory canals $10-15$ in diameter; dorsal osmoregulatory canals $5-10$ in diameter.

Scolex 285-380 $(\mathrm{x}=320, \mathrm{n}=4$; $\mathrm{TM}=345)$ in diameter, slightly wider than proliferation zone, without apical organ. Suckers uniloculate, 135-190 $(x=160, n$ $=16 ; \mathrm{TM}=150-180)$ in diameter, opening anteriolaterally (Figs. 3, 4, 6). Apex of scolex covered with filiform microtriches only (Fig. 5), external margin of suckers with filiform and blade-like spiniform microtriches (Fig. 7), sucker cavities with large blade-like spiniform microtriches up to 9 long, interspersed with filiform microtriches (Fig. 8), and anterior region of proliferation zone (neck) with filiform microtriches. Proliferation zone $1.2-1.8 \mathrm{~mm}$ long by $220-290$ wide.

Testes cortical, spherical to oval, 50-80 in diameter $(\mathrm{TM}=60-75), 77-109$ in number $(\mathrm{x}=92, \mathrm{n}=11, \mathrm{CV}=$ $13 \%$; $\mathrm{TM}=73-100, \mathrm{x}=88, \mathrm{n}=5$; more than 200 according to Woodland 1933), in one irregular field, in two or three layers, often absent in central part of proglottid, overlapping cirrus-sac and vagina, but not vas deferens, not reaching laterally to vitelline follicles (Fig. 20), present also in gravid proglottids.

Vas deferens (external sperm duct) coiled, between base of cirrus-sac and median part of proglottid, extending beyond the latter in mature and gravid proglottids. Cirrus-sac elongate, thick-walled, 210-325 (TM = 240 275 ) long by $110-145$ wide; $\mathrm{PC}=25-39 \%, \mathrm{n}=30$ (TM $=30-36 \%, \mathrm{n}=8)$. Ejaculatory duct coiled, thick-walled in distal part, thin-walled proximally. Cirrus occupying up to $78 \%(\mathrm{TM}=90 \%)$ of cirrus-sac length. Genital pores irregularly alternating, markedly pre-equatorial, $\mathrm{PP}=21-34 \%(\mathrm{x}=28 \%, \mathrm{n}=30, \mathrm{CV}=15 \%$; $\mathrm{TM}=24$ $32 \%, \mathrm{n}=12)$. Genital atrium present.

Ovary cortical, bilobed, with numerous dorsal outgrowths, $\mathrm{OV}=55-76 \%(\mathrm{x}=65 \%, \mathrm{n}=28, \mathrm{CV}=9 \%$; $\mathrm{TM}=71-76 \%, \mathrm{n}=7$ ) (Fig. 20). Mehlis' glands 55-75 in diameter, representing $6-8 \%$ of proglottid width
(Fig. 20). Vagina posterior (in $63 \%$ of proglottids) or anterior (in $37 \%$ of proglottids, $n=46)(\mathrm{TM}=$ posterior in $78 \%$ of proglottids, $n=14$ ) to cirrus-sac, with short thickened terminal portion surrounded by small vaginal sphincter (Fig. 20). Vitelline follicles cortical, arranged in two lateral bands; fields crescent-shaped in crosssections (Fig. 23), occupying almost entire proglottid length, interrupted at level of cirrus-sac (Fig. 20); ventral follicles more numerous than dorsal ones.

Uterus cortical, visible in immature proglottids, type 2 development (de Chambrier et al. 2004). Uterine stem occupying up to $25 \%$ of width of immature proglottids, lumen appearing in last immature proglottids developing into median field of undifferentiated chromophilic cells, then developing lateral elongate digitiform projections (lateral diverticula), sometimes ramified (Fig. 21). In mature proglottids, lumen extending gradually from base to apex of each diverticulum constituted by numerous chromophilic cells. Uterus in gravid proglottids with 14-27 (TM = 13-21) ramified lateral branches on each side comprising numerous chromophilic cells, occupying up to $76 \%(\mathrm{TM}=75 \%)$ of gravid proglottid width (Fig. 21).

Eggs spherical, with hyaline outer envelope 60-95 in diameter (Fig. 24). Embryophore thick, round to oval, consisting of two layers; outer layer larger than nucleicontaining envelope, $27-30 \times 30-33$ in diameter; oncospheres spherical, $12-13$ in diameter, with hooks $6.5-$ 7.5 long.

Remarks. Woodland (1933) described this cestode based on numerous specimens collected from "lenha" (field number Amaz 92) from the Amazon River 50 miles below Santarem, Brazil. It appears that Woodland's (1933) description of M. lenha was based on a mixed type series. Based on examination of the type material possessing testes and ovary positioned medullary, his figure 11 (plate 31 ) is likely an illustration of Nomimoscolex lenha, not Monticellia lenha. Furthermore, Woodland (1933) reported more than 200 testes in $M$. lenha, which in fact corresponds to the number of testes of $N$. lenha.

Freze (1965) proposed Spasskyellina to accommodate Monticellia lenha (type species) and M. spinulifera (Woodland, 1933) Freze, 1965, based on the presence of spines (in fact spiniform microtriches) on the suckers and precocious opening of the uterus, without well developed diverticula. However, Spasskyellina was synonymized with Monticellia by de Chambrier and Vaucher (1999) because these authors did not consider the presence of spiniform microtriches ("spines" according to Freze 1965) to justify erection of the former genus. Recently, the ultrastructure of three species Monticellia has been studied and each of them has a different type, distribution, size and density of microtriches (Gil de Pertierra 2004, 2005). Different patterns of microtriches among Monticellia taxa thus represent another evidence that does not justify the retention of Spasskyellina. 

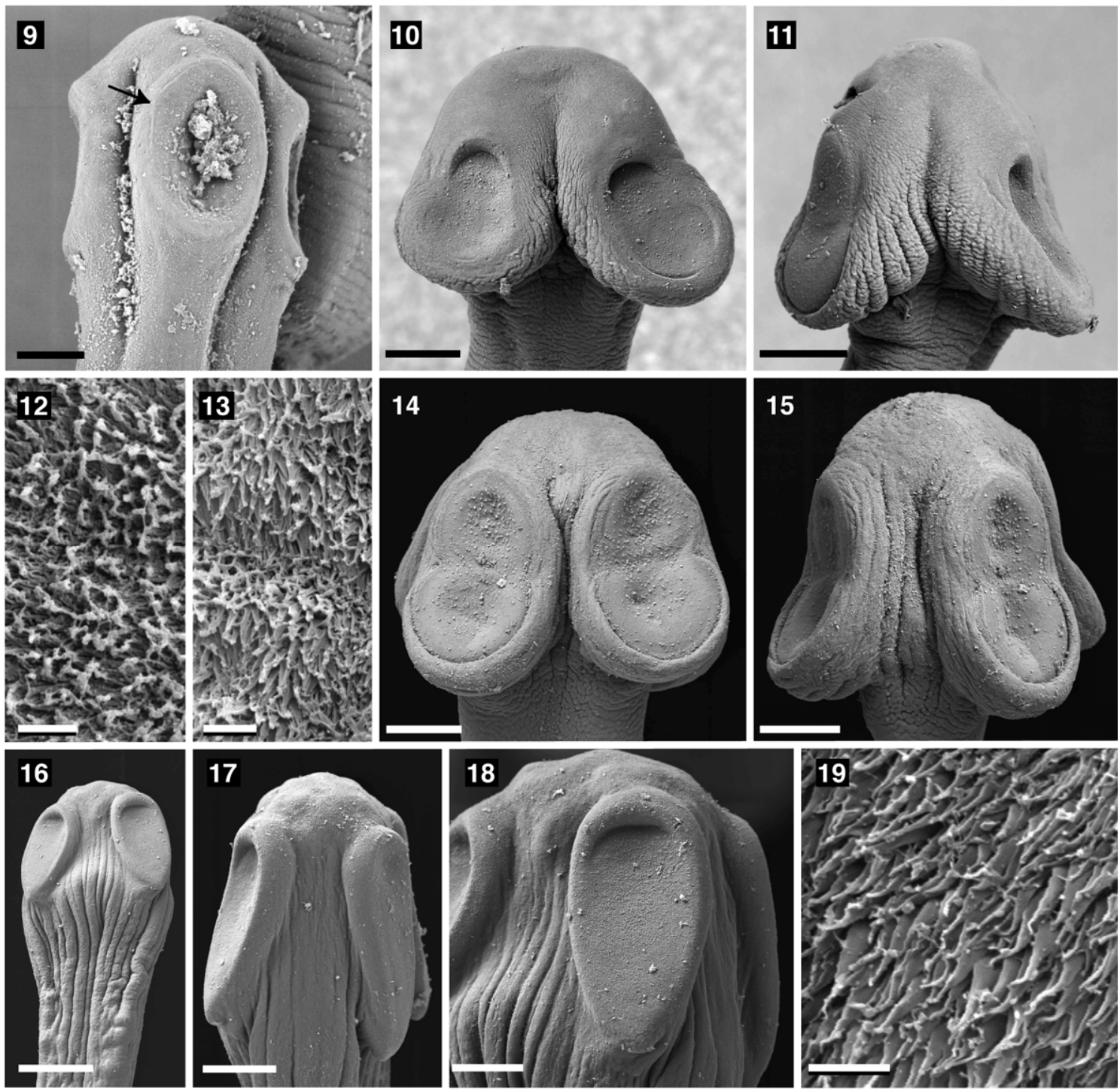

Figs. 9-19. Scanning electron micrographs. Fig. 9. Dorsoventral view of scolex of Nomimoscolex lenha (Woodland, 1933) Woodland, 1935 (syntype BMNH 1964.12.15.123-127); discrete cone-shaped, papilla-like projection at anterior abaxial margin of each sucker marked by arrow. Figs. 10-13. Lenhataenia megacephala (Woodland, 1934) comb. n. (INVE 54608). Fig. 10. Scolex in dorsoventral view. Fig. 11. Scolex in lateral view. Fig. 12. Filiform microtriches on the apex of scolex. Fig. 13. Filiform and spiniform microtriches between suckers. Figs. 14, 15. Scolex of Chambriella sp. (INVE 54609). Fig. 14. Dorsoventral view. Fig. 15. Lateral view. Figs. 16-19. Choanoscolex sp. (INVE 56610). Fig. 16. Scolex in dorsoventral view. Fig. 17. Scolex in lateral view. Fig. 18. Sucker. Fig. 19. Spiniform microtriches on proliferation zone (neck region). Scale bars: Figs. $9,18=50$ $\mu \mathrm{m}$; Figs. 10, 11, 14, $15=100 \mu \mathrm{m}$; Figs. 12, 13, $19=3 \mu \mathrm{m}$; Fig. $16=150 \mu \mathrm{m}$; Fig. $17=75 \mu \mathrm{m}$.

Monticellia lenha is considered to be valid by most authors and differs from other taxa found in S. planiceps in the shape of the scolex and presence of large, spinelike spiniform microtriches on the suckers. To date, no material of M. lenha has been available for sequencing and thus, its phylogenetic relationship to other proteocephalideans is unknown.

(3) Nomimoscolex lenha (Woodland, 1933) Woodland, 1935

Figs. 9, 25-35

Synonym: Proteocephalus lenha Woodland, 1933.

Redescription (based on cotypes BMNH 1964.12. $15.123-127$ and three specimens from S. planiceps from
Brazil and Peru): Proteocephalidae, Zygobothriinae. Testes, uterine stem and ovary medullary, with some dorsal ovarian outgrowths penetrating cortex, vitelline follicles cortical. Worms up to $155-235 \mathrm{~mm}$ long $(\mathrm{TM}=$ $159 \mathrm{~mm} ; 130 \mathrm{~mm}$ according to Woodland 1933), and $2.02 \mathrm{~mm}$ wide $(\mathrm{TM}=1.87 \mathrm{~mm} ; 2.59 \mathrm{~mm}$ according to Woodland 1933). Strobila acraspedote, covered with small filiform microtriches.

Internal longitudinal muscles developed (Figs. 27, $28,32,33$ ), forming anastomosed bundles of muscle fibres. Ventral osmoregulatory canals thin-walled, 2055 in diameter; dorsal osmoregulatory canals thickwalled, $5-8$ in diameter. 
Scolex 275-370 $(\mathrm{n}=2 ; \mathrm{TM}=250-335)$ in diameter, slightly wider than proliferation zone, without apical organ (Figs. 25, 26). Suckers uniloculate (Fig. 9), 130195 in diameter $(\mathrm{n}=8 ; \mathrm{TM}=85-150)$, bearing discrete cone-shaped, papilla-like projection at anterior abaxial margin of each suckers (Figs. 9, 25, 26, see arrows). Apex of scolex and external margins of suckers covered with filiform microtriches only. Proliferation zone 1.4 $2.5 \mathrm{~mm}$ long by 275-315 wide, with spiniform and filiform microtriches on anterior region.

Testes medullary, spherical to oval, $85-125$ in diameter, $371-421$ in number $(\mathrm{x}=377, \mathrm{n}=3, \mathrm{CV}=11 \%$; $\mathrm{TM}$ $=300-340, \mathrm{n}=2)$, in two fields between vitelline follicles, reaching to them, but almost not overlapping them, interrupted by uterus (Fig. 34), in one or two layers, present also in gravid proglottids.

Vas deferens coiled, occupying oval field between proximal part of cirrus-sac and anteromedian part of uterus, crossing over uterus in mature and gravid proglottids, extending slightly posterior to base of cirrus-sac (Figs. 31, 34). Cirrus-sac elongate, thin-walled (Fig. 31), 235-485 (TM = 380-495) long by 130-250 wide; $\mathrm{PC}=21-35 \%(\mathrm{x}=26 \%, \mathrm{n}=27, \mathrm{CV}=12 \%$; $\mathrm{TM}$ $=23-29 \%, \mathrm{n}=12)$. Ejaculatory duct coiled, thickwalled in terminal part; cirrus strongly sinuous, thinwalled in terminal part. Cirrus occupying up to $60 \%$ $(\mathrm{TM}=50 \%)$ of cirrus-sac length (Figs. 31, 34). Genital pores irregularly alternating, pre-equatorial, $\mathrm{PP}=31$ $45 \%(\mathrm{n}=30, \mathrm{CV}=11 \% ; \mathrm{TM}=25-35 \%, \mathrm{n}=12)($ Fig. 34). Genital atrium shallow.

Ovary medullary, bilobed, with numerous dorsal outgrowths in lateral parts, sometimes penetrating to cortex (Figs. 27, 29, 32, 34), OV = 66-77\% $(\mathrm{x}=73 \%, \mathrm{n}=26$, $\mathrm{CV}=4 \% ; \mathrm{TM}=73-78 \%, \mathrm{n}=11)$. Mehlis' glands 90 160 in diameter, representing $9-12 \%$ of proglottid width (Figs. 29, 34). Vagina posterior $(\mathrm{n}=193$; TM, $\mathrm{n}=48)$ to cirrus-sac, with short thickened distal portion surrounded by small vaginal sphincter, $40-55$ in diameter (Figs. 31, 34). Vitelline follicles cortical, small, arranged in two lateral rows; fields crescent-shaped in cross-section (Fig. 33), occupying almost entire length of proglottid, interrupted at level of cirrus-sac (Figs. 31, 34). Ventral follicles more numerous than dorsal ones (Fig. 33).
Uterus cortical, type 2 development (de Chambrier et al. 2004); uterine stem cortical in immature proglottids (Fig. 28), with subsequent development of uterine diverticula in medulla. Wall of uterine stem lined with numerous intensely-staining cells in immature proglottids. Uterine stem lumen appearing in last immature proglottids. Eggs present in uterus prior to development of uterine diverticula. Uterus with 16-28 $(\mathrm{TM}=24-30)$ lateral branches on each side, occupying up to $57 \%$ (TM $=50 \%$ ) of width of gravid proglottids.

Eggs spherical, with hyaline outer envelope (not figured in Fig. 30), slightly larger than embryophore (Fig. 35 ), about 25-28 in diameter. Embryophore thick, round, consisting of two layers; outer layer 21-22 (TM = 21-22) in diameter, thicker than nuclei-containing envelope; oncosphere spherical to oval, 11-12 (TM = 10 ) in diameter, with hooks 5-6 long (Figs. 30, 35).

Remarks. The taxon was erected as Proteocephalus lenha by Woodland (1933) on the basis of 12 specimens found in the intestine of "lenha", which also harboured type specimens of Peltidocotyle lenha (as Othinoscolex lenha) and Monticellia lenha (field number Amaz 92). The same author (Woodland 1935) transferred the species to Nomimoscolex Woodland, 1934 because of the cortical position of vitelline follicles. This combination has been widely accepted by subsequent authors (e.g., Freze 1965, Schmidt 1986, de Chambrier and Vaucher 1997, Rego et al. 1999, de Chambrier et al. 2004). Nomimoscolex lenha is a rather rare parasite of S. planiceps as indicated by low values of prevalence $(11 \%$ in Peru - de Chambrier et al. 2006b; 22\% in Brazil; $n=9)$.

In a multigene analysis of 53 proteocephalidean taxa by Hypša et al. (2005), N. lenha formed a monophyletic clade with three other species of Nomimoscolex, namely $N$. dorad Woodland, 1935, N. piraeeba Woodland, 1934 (type species) and $N$. suspectus Zehnder, de Chambrier, Vaucher et Mariaux, 2000; N. lenha appeared as the basal taxon of this group. Three other congeneric taxa sequenced, N. admonticellia (Woodland, 1934) Rego et Pavanelli, 1992, N. lopesi Rego, 1989 and N. sudobim Woodland, 1935, however, placed in a clade also containing several genera of Neotropical proteocephalideans (Hypša et al. 2005). These species of Nomimo-

Figs. 20-24. Monticellia lenha Woodland, 1933. Fig. 20. Mature proglottid in dorsal view (syntype, BMNH 1964.12.15.225231). Fig. 21. Gravid proglottid, sketch (INVE 19510). Fig. 22. Cross-section at level of cirrus-sac (INVE 19510). Fig. 23. Cross-section at level of cirrus-sac (syntype, BMNH 1964.12.15.225-231). Fig. 24. Eggs drawn in distilled water (INVE 20500). Figs. 25-35. Nomimoscolex lenha (Woodland, 1933) Woodland, 1935. Fig. 25. Scolex (syntype, BMNH 1964.12.15.123-127). Fig. 26. Scolex (IPCAS C-477). Arrow in Figs. 25 and 26 indicates discrete cone-shaped, papilla-like projection. Fig. 27. Partial cross-section showing ovarian follicles penetrating dorsal cortex (syntype, BMNH 1964.12.15.123-127). Fig. 28. Partial crosssection showing cortical position of uterine stem (syntype, BMNH 1964.12.15.123-127). Fig. 29. Posterior part of proglottid showing dorsal ovarian follicles (syntype, BMNH 1964.12.15.123-127). Fig. 30. Immature egg drawn in whole preparation (syntype, BMNH 1964.12.15.123-127). Fig. 31. Vagina and cirrus-sac region (syntype, BMNH 1964.12.15.123-127). Fig. 32. Cross-section at level of ovary (INVE 20697). Fig. 33. Cross-section at level of anterior part of proglottid (INVE 20697). Fig. 34. Pregravid proglottid in ventral view (INVE 20697). Fig. 35. Eggs drawn in distilled water (INVE 54629). Abbreviations: $\mathrm{dc}$ - dorsal osmoregulatory canal; em - embryophore; lm - internal longitudinal musculature; mg - Mehlis' glands; oe - outer envelope; om - oncospheral membrane; on - oncosphere; ov - ovary; te - testes; ut - uterus; vc - ventral osmoregulatory canal; vd - vitelloduct; vi - vitelline follicles. Scale bars: Figs. 20-23, 29, 31-33 =500 $\mu \mathrm{m}$; Fig. $24=50 \mu \mathrm{m}$; Figs. $25,27=250 \mu \mathrm{m}$; Figs. 26, $28=100 \mu \mathrm{m}$; Figs. 30, $35=20 \mu \mathrm{m}$; Fig. $34=1 \mathrm{~mm}$. 

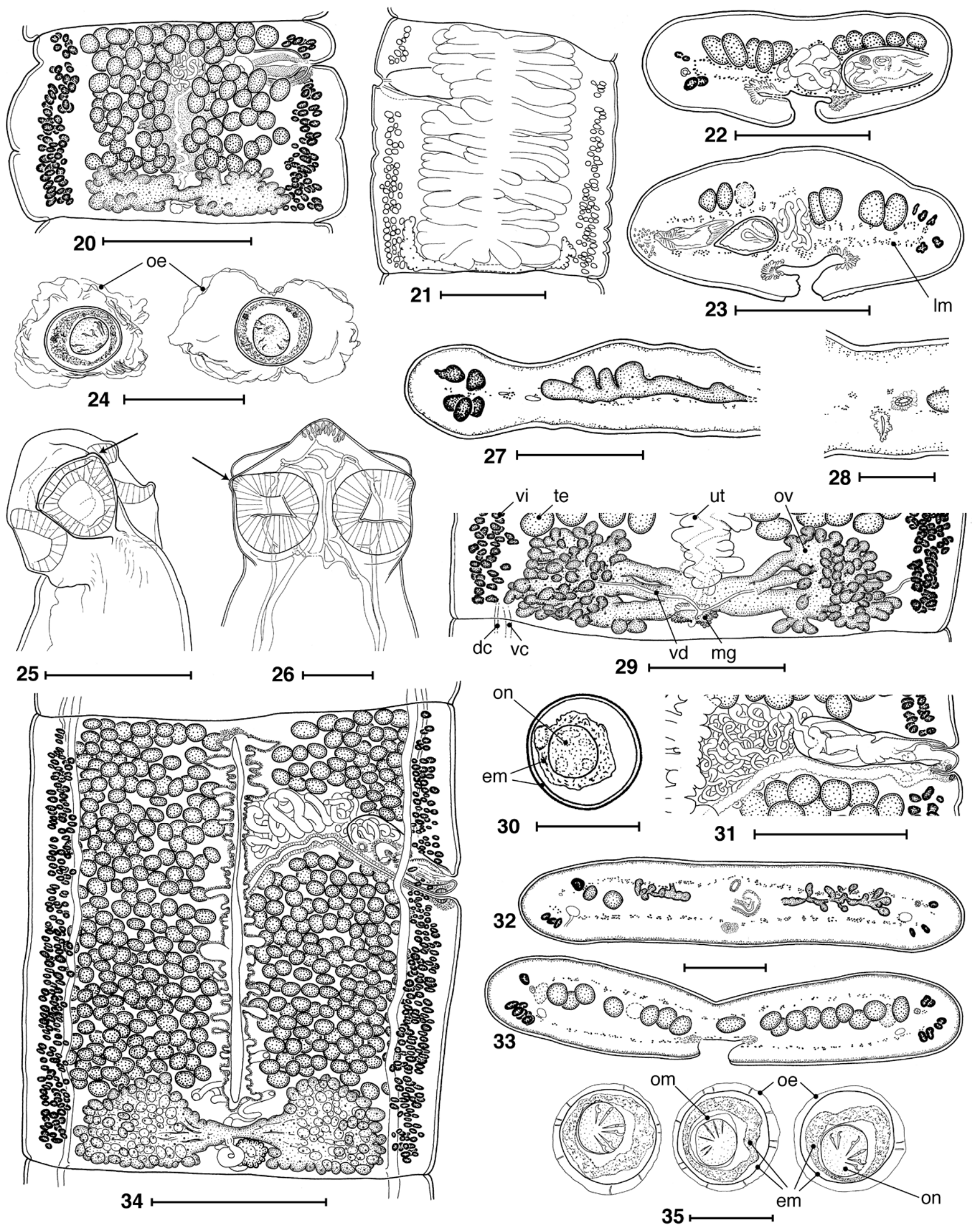
scolex were more closely related to the Peltidocotyle clade than to those taxa of Nomimoscolex that formed a clade with $N$. lenha. These analyses, as well as those by Zehnder et al. (2000), indicate that the genus is not monophyletic as it is currently recognized and a revision of the genus is needed.

(4) Lenhataenia megacephala (Woodland, 1934) comb. n. Figs. 10-13, 36-42 1934

Synonym: Monticellia megacephala Woodland,

\section{Lenhataenia gen. n.}

Diagnosis. Proteocephalidea, Proteocephalidae, Monticelliinae. Testes, ovary, vitelline follicles and uterus cortical. Scolex without metascolex; suckers large, with free posterior margin overlapping narrow proliferation zone, pear-shaped, biloculate, posterior loculus wider than elongate anterior loculus. Testes in one field. Cirrus-sac elongate, thick-walled. Internal sperm duct thick-walled, forming several coils in proximal part of cirrus-sac. Genital pores irregularly alternating, preequatorial. Genital atrium present. Ovary with numerous dorsal outgrowths of lateral wings. Vagina posterior or anterior to cirrus-sac, with short thickened portion surrounded by ring-like vaginal sphincter formed by diffuse muscle fibres. Vitelline follicles small, arranged in two lateral rows, crescent-shaped in cross-section, occupying almost entire length of proglottids, with fewer follicles at level of cirrus-sac. Ventral follicles more numerous than dorsal ones. Uterine development of type 2 according to de Chambrier et al. (2004). Type and the only species: Lenhataenia megacephala (Woodland, 1934) comb. n. (syn. Monticellia megacephala Woodland, 1934).

E t y m o lo g y: The generic name is derived from the Portuguese name of fish host, "lenha", and a tapeworm, "Taenia"; it should be treated as feminine.

Differential diagnosis. The new genus belongs to the Monticelliinae because of the genital organs being situated in the cortex (Rego 1994). It differs from all genera of the Monticelliinae, except Chambriella, in lacking a metascolex and in possessing a four-lobed scolex with biloculate suckers (Figs. 10, 11, 36, 37). Chambriella can be easily distinguished from Lenhataenia in the morphology of the cirrus-sac, which is sigmoid and contains a dilated, voluminous, tightly sinuous internal sperm duct, forming a structure resembling an internal seminal vesicle (Figs. 43, 47), whereas the cirrus-sac of Lenhataenia contains narrow, thickwalled and coiled internal sperm duct (Fig. 42). This latter condition of the cirrus-sac is the more common condition in proteocephalideans. Chambriella and Lenhataenia also differ from each other in the development of internal longitudinal musculature, which is well developed in Lenhataenia, being formed by numerous small bundles of muscle fibres (Figs. 38, 39), whereas that of Chambriella is weakly developed, formed by a very few (less than 10) small bundles of muscle fibres (Fig. 45).

Redescription of Lenhataenia megacephala (Woodland, 1934) comb. n. (based on cotypes BMNH 1964. 12.15.199-205 and six specimens from S. planiceps from Brazil and Peru): Proteocephalidae, Monticelliinae. Testes, ovary, uterus and vitelline follicles cortical. Worms up to $21-25 \mathrm{~mm}$ long (24 $\mathrm{mm}$ according to Woodland 1934) and up to 705 wide (TM $=1,065$; 1,060 according to Woodland 1934). Strobila acraspedote, covered with small filiform microtriches only, consisting of 43-101 proglottids: 36-89 immature, only 5-10 mature, 2 pregravid (type material is fragmented and thus the number of proglottids could not be counted). Three gravid proglottids found only in one cotype specimen.

Internal longitudinal musculature well developed, formed by numerous small bundles of muscle fibres (Figs. 38, 39). Ventral osmoregulatory canals 20-40 in diameter; dorsal canals 5-10 in diameter.

Scolex $820-1,190$ in diameter $(\mathrm{x}=960, \mathrm{n}=7 ; \mathrm{TM}=$ 565-820; 530-790 according to Woodland 1934) wider than proliferation zone, without apical organ (Fig. 36). Apical region of scolex with numerous, anastomosed osmoregulatory canals. Suckers biloculate (Figs. 10, 11, $36,37)$, oriented anteriolaterally, 470-675 long ( $\mathrm{x}=$ $530, \mathrm{n}=27 ; \mathrm{TM}=290-395)$ by $260-390$ wide in posterior loculus $(\mathrm{x}=310, \mathrm{n}=8)$. Apex of scolex covered with filiform microtriches only (Fig. 12), region between suckers with spiniform and filiform microtriches (Fig. 13). Proliferative zone about 840-895 long by 240-320 wide, covered with spiniform microtriches in anterior region.

Figs. 36-42. Lenhataenia megacephala (Woodland, 1934) comb. n. Fig. 36. Scolex (syntype, BMNH 1964.12.15.199-205). Fig. 37. Biloculate sucker, showing posterior loculus wider than anterior loculus (IPCAS C-480). Figs. 38, 39. Cross-sections at level of ovary and anterior part of proglottid, respectively (syntype, BMNH 1964.12.15.199-205). Fig. 40. Gravid proglottid in ventral view (syntype, BMNH 1964.12.15.199-205). Fig. 41. Pregravid proglottid in dorsal view (INVE 22025). Fig. 42. Vagina and cirrus-sac region. Note the long ejaculatory canal. Figs. 43-46. Chambriella sp. Fig. 43. Vagina and cirrus-sac region. Note the shape of the internal seminal duct. Fig. 44. Scolex (IPCAS C-478). Fig. 45. Cross-section at level of vaginal canal (on the slide with the syntype of Lenhataenia megacephala, BMNH 1964.12.15.199-205). Fig. 46. Pregravid proglottid in ventral view (INVE 22027). Fig. 47. Partial cross-section at level of cirrus-sac (INVE 22027). Fig. 48. Scolex of Choanoscolex sp. (on the slide with the syntype of Lenhataenia megacephala, BMNH 1964.12.15.199-205). Abbreviations: ci - cirrus; cs - cirrus-sac; ed - vas deferens (external sperm duct); id - internal sperm duct; va - vagina; vs - vaginal sphincter. Scale bars: Figs. 36, 37, 42, $44,45,48=250 \mu \mathrm{m}$; Figs. 38-41, $46=500 \mu \mathrm{m}$; Figs. 43, $47=100 \mu \mathrm{m}$. 


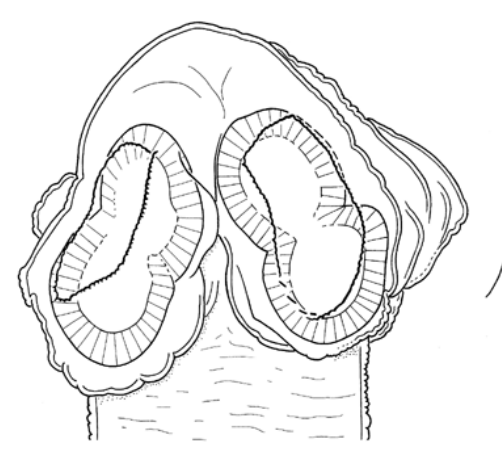

36

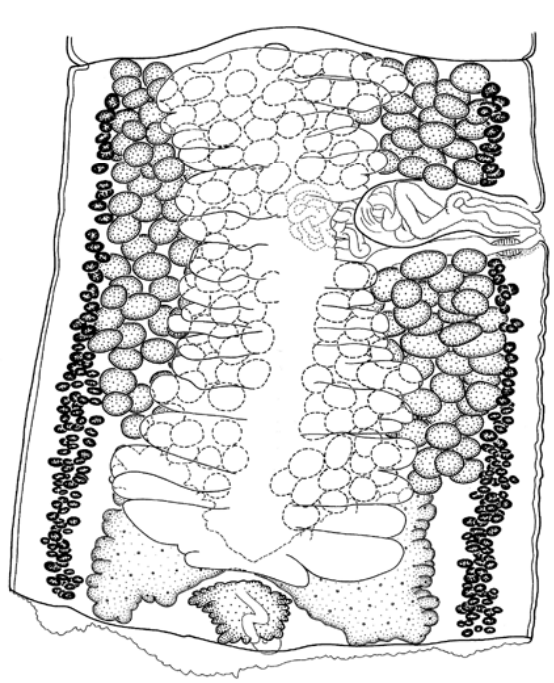

40

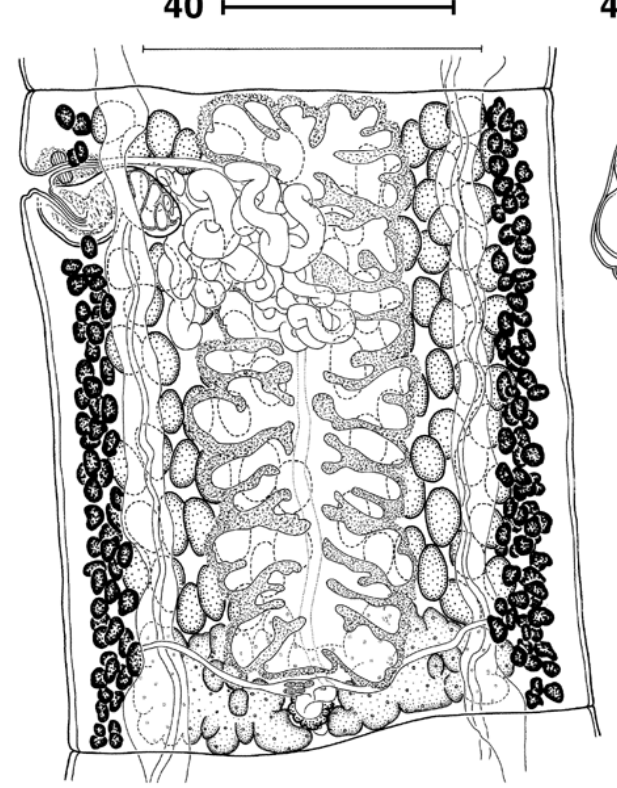

46

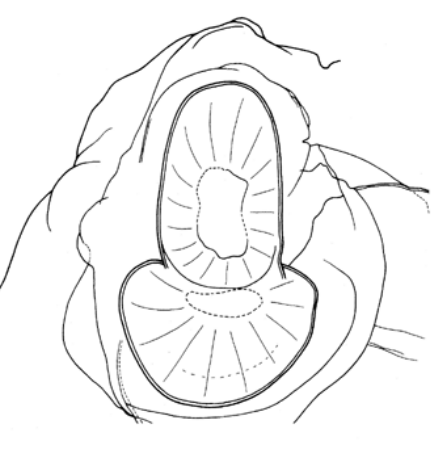

$37 \longmapsto$

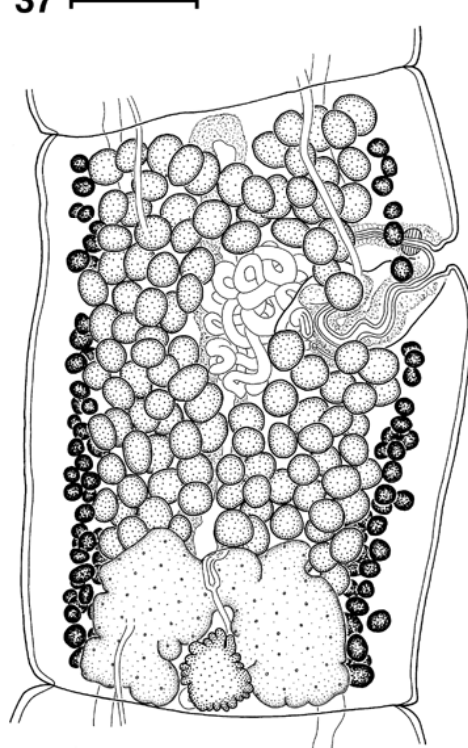

41
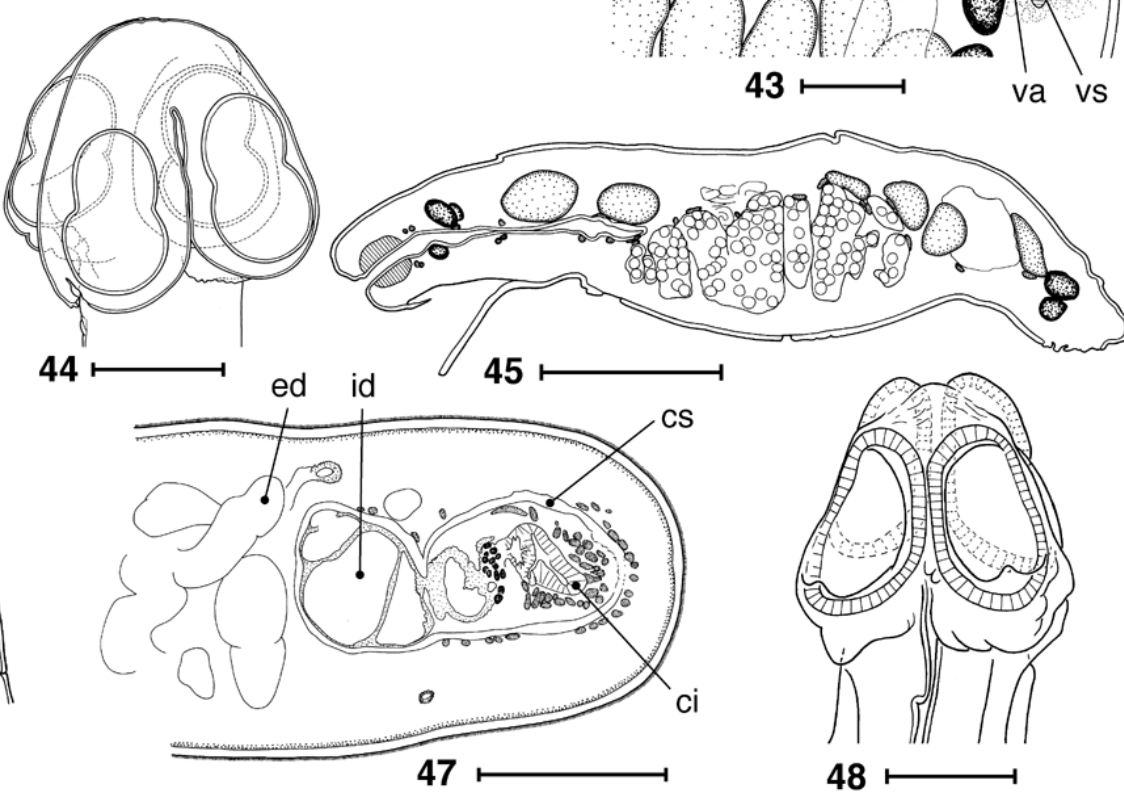
Testes cortical, spherical to oval, $40-80$ in diameter, $119-175$ in number $(\mathrm{n}=2 ; \mathrm{TM}=104-188, \mathrm{n}=5, \mathrm{x}=$ 130; about 200 according to Woodland 1934), in one or two layers (Figs. 39-41), forming one field reaching laterally up to vitelline follicles (Fig. 41), present also in gravid proglottids (Fig. 40). Vas deferens (external sperm duct) coiled, occupying field between proximal part of cirrus-sac and median part of uterus, overlapping slightly to poral part of mature and gravid proglottids, extending slightly posterior to base of cirrus-sac.

Cirrus-sac pyriform, distal part thick-walled, 190 260 long $(\mathrm{TM}=180-380)$ by $130-150$ wide; $\mathrm{PC}=31-$ $41 \%(\mathrm{TM}=29-46 \%, \mathrm{n}=17)$. Internal sperm duct narrow, thick-walled, strongly coiled in proximal part of cirrus-sac; cirrus occupying up to $80 \%(\mathrm{TM}=72 \%)$ of length of cirrus-sac (Fig. 42). Genital pores, irregularly alternating, pre-equatorial (Figs. 40-42), $\mathrm{PP}=25-41 \%$ $(\mathrm{x}=32 \%, \mathrm{n}=16, \mathrm{CV}=18 \% ; \mathrm{TM}=23-33 \%, \mathrm{n}=10)$. Genital atrium present.

Ovary cortical, bilobed, with numerous dorsal outgrowths of lateral wings (Fig. 38), $\mathrm{OV}=62-70 \%$ ( $\mathrm{x}=$ $66 \%, \mathrm{n}=16, \mathrm{CV}=4 \% ; \mathrm{TM}=58-77 \%, \mathrm{n}=17)$. Mehlis' glands $105-245$ in diameter, representing $15-22 \%$ of proglottid width (Figs. 40, 41). Vagina posterior (in $65 \%$ of proglottids) or anterior (in $35 \%$ of proglottids, $n$ $=68)$ to cirrus-sac, with short thickened portion surrounded by ring-like vaginal sphincter formed by diffuse muscle fibres (Fig. 42). Vitelline follicles cortical, small, arranged in two lateral rows; fields crescentshaped in cross-sections (Figs. 38, 39), occupying almost entire length of proglottids, with fewer follicles at level of cirrus-sac (Figs. 41, 42). Ventral follicles more numerous than dorsal ones (Fig. 38).

Uterus cortical, type 2 development (de Chambrier et al. 2004); uterine stem cortical in immature proglottids with numerous intensely-staining cells concentrated along its wall; uterine lumen appearing in last immature proglottids. Eggs present prior development of uterine diverticula. Uterus with 17-21 (TM $=14-21)$ lateral branches (diverticula) on each side, occupying up to $55 \%$ of width of gravid proglottids (Fig. 40).

Eggs spherical; embryophore thick, round, consisting of two layers; outer layer (TM) 20-23 in diameter, thicker than nuclei-containing envelope; oncosphere spherical to oval, (TM) 12-15 in diameter (measured in whole mounts) (fig. 30 on plate 2 of Woodland 1934).

Remarks. The species was described by Woodland (1934) as Monticellia megacephala from five specimens found in "lenha" caught at Codajaz, about 150 miles above Manaus (field number Amaz 19) and one specimen from the fish collected in the Amazon River 50 miles below Santarem, Brazil (field number Amaz 92).

Lenhataenia megacephala differs from other proteocephalideans by the characters listed in the generic diagnosis of Lenhataenia. It somewhat resembles Chambriella sp. found in S. planiceps in this study (see below). However, the tapeworms are easy to distinguish on the basis of markedly different morphology of their cirrus-sac and development of the inner longitudinal musculature (the generic differences between Lenhataenia and Chambriella), morphology of the vaginal sphincter (elongate, formed by diffuse concentration of muscle fibres, not well delimited in the former taxon versus ring-like, well delimited in Chambriella sp.), size of the scolex (larger in L. megacephala), and a slightly different shape of the suckers (markedly pyriform in $L$. megacephala, whereas 8-shaped in Chambriella sp.).

Woodland (1934 - fig. 27) illustrated scoleces of three specimens of tapeworms considered to belong to M. megacephala, but one of these (fig. 27C) in fact illustrates a species of Choanoscolex La Rue, 1911 (see Fig. 48), most probably conspecific with the one recently found by the present authors (Figs. 16-18).

\section{(5) Chambriella sp.}

Figs. 14, 15, 43-47

Remarks. Besides the species listed above, two other proteocephalidean cestodes were found in S. planiceps from Brazil and Peru. One species belongs to Chambriella, because it possesses biloculate suckers and a cirrus-sac typical of the genus, i.e., the cirrus-sac is sigmoid and contains a dilated, voluminous, tightly sinuous internal sperm duct, which resembles an internal seminal vesicle (Figs. 43, 47). The tapeworms from S. planiceps may represent a taxon new to science but are here provisionally designated as Chambriella sp. until more material is available for a more detailed comparative study.

\section{(6) Choanoscolex sp.}

Figs. 16-19, 48

Remarks. Another proteocephalidean found in $S$. planiceps in Brazil and Peru is most likely a member of the genus Choanoscolex La Rue, 1911 (Monticelliinae) because it possesses a weakly developed metascolex posterior to the suckers. The suckers are elongate and their posterior margins are tapered (Figs. 16-18; see de Chambrier and Vaucher 1999). The taxon found in $S$. planiceps differs slightly from Choanoscolex abscisus (Riggenbach, 1896), the only species currently placed in Choanoscolex, in some morphological characteristics and may represent a new species. However, only a few, mostly immature specimens were found in Brazil and Peru (de Chambrier et al. 2006b).

\section{Key to the species of proteocephalidean cestodes from Sorubimichthys planiceps}

In order to facilitate further research of the cestodes parasitic in Neotropical freshwater fish, a key to identification of the species from firewood catfish, Sorubimichthys planiceps, is provided.

1 Metascolex (enlarged part of the posterior part of scolex with tegumental wrinkles) present ............... 2

- Metascolex absent .................................................. 3 
2 Suckers uniloculate, elongate, tapered posteriorly; metascolex weakly developed, posterior to suckers Choanoscolex sp.

- Suckers biloculate; metascolex large, well developed ......................................... Peltidocotyle lenha

3 Suckers uniloculate .............................................. 4

- Suckers biloculate ................................................. 5

4 Large tapeworms; suckers without large spiniform microtriches; vagina always posterior to cirrus-sac; uterus without intensely-stained cells on apex of uterine diverticula .................. Nomimoscolex lenha

- Small tapeworms; suckers with large spiniform microtriches; vagina posterior or anterior to cirrussac; uterus with intensely-stained cells on apex of uterine diverticula Monticellia lenha

5 Cirrus-sac with voluminous, tightly sinuous internal sperm duct Chambriella sp.

- Cirrus-sac without voluminous, tightly sinuous internal sperm duct Lenhataenia megacephala
Acknowledgements. We thank David I. Gibson and Eileen Harris (both BMNH) for loan of the type material of W.N.F. Woodland and Jean Mariaux for fruitful suggestions, André Piuz for taking scanning electron micrographs, Gilles Roth and Florence Marteau for help with drawings, and Janik Pralong (all MHNG) and Martina Borovková (IPCAS) for technical help. Invaluable suggestions of Kirsten Jensen, University of Kansas, USA, are also greatly appreciated. The authors are also indebted to Roman Kuchta (IPCAS) and Amilcar Arandas Rego (Rio de Janeiro, Brazil), who helped collect tapeworm specimens in Peru and Brazil, respectively, to Martin Mortenthaler (Iquitos, Peru), who provided facilities for fish examination and supported the stays of T.S. and R. Kuchta in Iquitos, and to numerous Peruvian colleagues and institutions, especially Fernando G. Poma Castillo, Emer Gloria Pizango Paima, Germani Merino Gasterú, Government of the Loreto Region, Faculty of Biological Sciences of the National University of Peruvian Amazonia (UNAP) in Iquitos, and Peruvian and Czech Embassies in Prague and Lima, respectively. Financial support of the Grant Agency of the Czech Republic (projects Nos. 524/04/0342 and 524/03/H133) and the Institute of Parasitology (projects Nos. Z60220518 and LC 522) to T.S. is also acknowledged.

\section{REFERENCES}

CARFORA M., DE CHAMBrIER A., VAUCHER C. 2003: Le genre Amphoteromorphus (Cestoda: Proteocephalidea), parasite de poissons-chats d'Amérique tropicale: étude morphologique et approche biosystématique par électrophorèse des protéines. Rev. Suisse Zool. 110: 381-409.

DE CHAMBRIER A. 2003: Redescription of Manaosia bracodemoca Woodland, 1935 and Paramonticellia itaipuensis Pavanelli et Rego, 1991 (Eucestoda, Proteocephalidea), parasites of Sorubim lima (Siluriformes, Pimelodidae) from South America. Folia Parasitol. 50: 121-127.

DE Chambrier A., Rego A.A., Gil DE Pertierra A. 2005: Redescription of two cestodes (Eucestoda: Proteocephalidea) parasitic in Phractocephalus hemioliopterus (Siluriformes) from the Amazon and erection of Scholzia gen. n. Rev. Suisse Zool. 112: 735-752.

DE CHAMBrier A., SCHOlz T. 2005: Redescription of Houssayela sudobim (Eucestoda: Proteocephalidea), a parasite of Pseudoplatystoma fasciatum (Siluriformes) from the Amazon River. Syst. Parasitol. 62: 161-169.

De Chambrier A., Scholz T., KuChta R., Posel P., MortenTHALER M., CHUQUiPIONDO-GUARDiA C. 2006b: Tapeworms (Cestoda: Proteocephalidea) of fishes from the Amazon River in Peru. Comp. Parasitol. 73: 111-120.

DE Chambrier A., TAKemoto R.M., PAVAnElli G.C. 2006a Nomimoscolex pertierrae n. sp. (Eucestoda: Proteocephalidea), a parasite of Pseudoplatystoma corruscans (Siluriformes: Pimelodidae) in Brazil and redescription of Nomimoscolex sudobim Woodland, 1935, a parasite of $P$. fasciatum. Syst. Parasitol. 64: 191-202.

DE CHAMBrier A., VAUCHER C. 1997: Révision des cestodes (Monticelliidae) décrits par Woodland (1934) chez Brachyplatystoma filamentosum avec redéfinition des genres Endorchis Woodland, 1934 et Nomimoscolex Woodland, 1934. Syst. Parasitol. 37: 219-233.

DE CHAMBrier A., VAUCHER C. 1999: Proteocephalidae et Monticelliidae (Eucestoda: Proteocephalidea) parasites de poissons d'eau douce du Paraguay avec descriptions d'un genre nouveau et de dix espèces nouvelles. Rev. Suisse Zool. 106: $165-240$
De Chambrier A., Zehnder M.P., VAucher C., MariauX J. 2004: The evolution of the Proteocephalidea (Platyhelminthes, Eucestoda) based on an enlarged molecular phylogeny, with comments on their uterine development. Syst. Parasitol. 57: 159-171.

FREZE V.I. 1965: [Proteocephalata in Fish, Amphibians and Reptiles]. Essentials of Cestodology. Vol. V. Nauka, Moscow, 538 pp. (In Russian: English translation, Israel Program of Scientific Translation, 1969, Cat. No. 1853. v + 597 pp.).

Froese R., PAuly D. (Eds.) 2007: FishBase. World Wide Web electronic publication. www.fishbase.org, November 2007.

GIL DE PERTIERRA A.A. 2004: Redescription of Monticellia magna (Rego, dos Santos \& Silva, 1974) (Eucestoda: Monticelliidae) parasite of Pimelodus spp. (Pisces: Siluriformes) from Argentina, and morphological study of microtriches. Rev. Suisse Zool. 111: 11-20.

GIL DE PERTIERRA A.A. 2005: Comparative study of the microtriches of adult cestodes (Proteocephalidea: Monticelliidae), and some comments on their systematic value. Zool. Anz. 243: 295-304.

Gil De Pertierra A.A., DE CHAMBrier A. 2000: Rudolphiella szidati sp. n. (Proteocephalidea: Monticelliidae, Rudolphiellinae) parasite of Luciopimelodus pati (Valenciennes, 1840) (Pisces: Pimelodidae) from Argentina with new observations on Rudolphiella lobosa (Riggenbach, 1895). Rev. Suisse Zool. 107: 8195.

HoBERG E.P., SIMS D.E., ODENSE P.H. 1995: Comparative morphology of the scolices and microtriches among five species of Tetrabothrius (Eucestoda: Tetrabothriidae). J. Parasitol. 81: $475-481$.

HYPŠA V., ŠKEŘíKOVÁ A., SCHOLZ T. 2005: Phylogeny, evolution and host-parasite relationships of the order Proteocephalidea (Eucestoda) as revealed by combined analysis and secondary structure characters. Parasitology 130: 359-371.

REgO A.A. 1994: Order Proteocephalidea Mola, 1928. In: L.F. Khalil, A. Jones and R.A. Bray (Eds.), Keys to the Cestode Parasites of Vertebrates. CAB International, Wallingford, Oxon, UK, pp. 257-293. 
Rego A.A., Chubb J.C., Pavanelli G.C. 1999: Cestodes in South American freshwater teleost fishes: keys to genera and brief description of species. Rev. Brasil. Zool. 16: 299-367.

SCHMIDT G.D. 1986: CRC Handbook of Tapeworm Identification. CRC Press, Boca Raton, Florida, 675 pp.

THOMPSON R.C.A., HAYTON A.R., JUE SUE L.P. 1980: An ultrastructural study of the microtriches of adult Proteocephalus tidswelli (Cestoda: Proteocephalidea). Z. Parasitenkd. 64: 95111.

WOODLAND W.N.F. 1933: On a new subfamily of proteocephalid cestodes - the Othinoscolecinae - from the Amazon siluroid fish Platystomatichthys sturio (Kner). Parasitology 25: 491500.

WoODLAND W.N.F. 1934: On six new cestodes from Amazon fishes. Proc. Zool. Soc. London 104: 33-44.

Received 23 August 2007
WOODLAND W.N.F. 1935: Some more remarkable cestodes from Amazon siluroid fish. Parasitology 27: 207-225.

ZEHNDER M.P., DE CHAMBRIER A. 2000: Morphological and molecular analyses of the genera Peltidocotyle Diesing 1850 and Othinoscolex Woodland 1933, and a morphological study of Woodlandiella Freze, 1965 (Eucestoda, Proteocephalidea), parasites of South American siluriform fishes (Pimelodidae). Syst. Parasitol. 46: 33-43.

Zehnder M.P., De Chambrier A., VAucher C., MariauX J. 2000: Nomimoscolex suspectus n. sp. (Eucestoda: Proteocephalidea: Zygobothriinae) with morphological and molecular phylogenetic analyses of the genus. Syst. Parasitol. 47: 157172.

ZEHNDER M.P., MARIAUX J. 1999: Molecular systematic analysis of the order Proteocephalidea (Eucestoda) based on mitochondrial and nuclear rDNA sequences. Int. J. Parasitol. 29: 1841-1852.

Accepted 26 November 2007 